\title{
HOW INSTITUTIONS SHAPE UNCERTAINTY AND RISK
}

\author{
${ }^{1}$ Stephanie Tonn Goulart Moura, Christian Daniel Falaster, Christine Elena Bianchi, \\ Érica de Souza Mazato \& Laura Taysa Espig \\ Fundação Universidade Regional de Blumenau - FURB, Santa Catarina, (Brasil)
}

\begin{tabular}{l}
\hline ARTICLE DETAILS \\
\hline Article history: \\
Received: 11 April 2020 \\
Accepted: 29 June 2021 \\
Available online September: 01 th 2021 \\
Double Blind Review System \\
Scientific Editor \\
Ilan Avrichir \\
\hline Keywords \\
New Institutional Economics \\
Risk \\
Uncertainty \\
Institutions \\
Decision Making
\end{tabular}

\section{Introduction}

Risk and uncertainty are inherent in the business environment. This study aims to discuss the interrelationship between risk and uncertainty, understood in this work as subsequent concepts (Magnani \& Zucchella, 2018). The existence of one may depend on the degree of the other. Companies need to cope with several challenges and decisionmaking scenarios to adequate their strategies to different levels of risk and uncertainty. One way of doing so is relying on conformity with institutions to gain legitimacy. In this regard, the present paper proposes a theoretical discussion about the influence

\footnotetext{
${ }^{1}$ Contact of the author E-mail: stephaniemr600@gmail.com
}

of formal and informal institutions on risk and uncertainty.

The institutional theory considers that firms have limited capacity for analysing scenarios that may influence the decision-making process and that, in search of reducing uncertainties, they rely on institutions in an attempt to legitimise their conduct (North, 1991, Francis, Zheng \& Mukherji, 2009). Institutions are formal rules, such as laws, regulations imposed by governments, and informal rules, such as culture and values, derived from the social structure itself (North, 1991, Tamanaha, 2015). These rules assume the desired behaviour in the locations, and actions aligned with them seem legitimate and proper behaviour (Suchman, 1995).
Purpose: The study proposes a conceptual framework on how institutions the existing literature the role of institutions in shaping risks and uncertainties remains understudied. This paper adopts the new institutional economics (NIE) perspective to revisit the concepts of risk and uncertainty and provide a deeper

Method: Our conceptual model is based on four propositions that support a theoretical explanation about the relationships between institutions and

Findings: While formal institutions have a primary role in reducing uncertainties, informal institutions can be seen as a source of risk. These findings imply firms' strategic decisions. In this regard, we also provide a

Originality/value: The study highlights the importance of institutions for companies to deal with risk and uncertainties. The institutions have a primary role in defining the "known part" of the uncertainty, allowing the companies to

Theoretical/Methodological Contributions: This study differentiates risk and and uncertainties. 
Companies operate in an environment that is inherently complex and permeated by risks and uncertainty. The set of formal and informal institutions shapes the interaction between companies and their strategic decision-making (Peng et al., 2008). At the same time, institutions constraint company behaviour. NIE analyses institutional rules as beneficial restrictions that seek to maximise the interest of economic actors within these limitations (Tamanaha, 2015), reducing uncertainties and risk.

Some perspectives that intend to understand the dynamics of decision making through risks and uncertainties involve economic theory (Knight, 1921), decision-making theory (Garner, 1962; Keeney, 1982), contingency theory (Lawrence and Lorsch, 1967), and institutional theory (Hall \& Soskice, 2004; Müllner, 2016; North, 1990; Porta et al., 2008). On risk, studies have been developed from the economic perspective (Dequech, 2018; Garner, 1962; Knight, 1921; Williamson, 1976) as well as in management perspective (Lewis \& Bozos, 2019; Müllner, 2016; Teece \& Leih, 2016).

Knight described one of the first concepts of uncertainty and risk in 1921. Knightian uncertainty is seen as a phenomenon in which the results are unknown. Its variation probabilities are unpredictable (Garner, 1962; Knight, 1921), but the risk represents a "known" part of the uncertainty. According to this understanding, the risk is associated with the circumstance in which the measurement of the probabilities of possible results are calculable and predictable, whereas the uncertainty arises from the impossibility of calculating or forecasting; it is related to uncertain and unknown future results (Knight, 1921).

What makes it interesting is that there are also different perceptions of the relationship of institutions with risk and uncertainty in addition to the different perceptions of risk and uncertainty. North (1991) hinted that institutions help transform uncertainties into risk. But how this could be done still understudied. In this study, we propose a theoretical explanation about the relationships between institutions and uncertainties, institutions and risks. Given these relationships, we raised the question: what role do institutions play in the relationship between uncertainties and risks? This perspective conceptualises a more in-depth analysis of the dynamics of these constructs. Understanding this difference is critical to understand better the dynamic regarding institutions from locals where firms operated.

We have contributed to NIE by developing a more detailed explanation of how the concepts of uncertainty, risk, and institutions interact with each other. This contribution is divided into three stages: firstly, we contribute with an explanation that differentiates the risk. Secondly, we proposed how uncertainty is affected by risk and differs from it. Thirdly, we develop two propositions of institutional restrictions that exert influence on the environment, thus, influencing risk and uncertainty.

\section{Institutions}

NIE has an economic nature and proposes that institutions are the set of rules which determine economic and social interactions (Agboola, 2015; de Groot et al., 2004; Hall \& Soskice, 2001, 2004; North, 1990). In turn, the institutional environment is the set of institutions that influence companies in a specific country or industry (Kostova \& Roth, 2002; Tywoniak et al., 2007). Hence, companies will behave according to the set of "rules of the game" present in the institutional environment they operate in (Peng et al., 2008).

Institutions are complex structures that restrict and outline social and economic interactions in a society (North, 1991). Thus, a range of essential social ties characterises the environment, such as language, money, laws, structuring economic activities (Tamanaha, 2015). NIE recognises that companies operate in a context of uncertainty regarding the effectiveness of their market strategies. This means that when companies do not understand the economic system as a whole, they rely on existing institutions to make their decisions, seeking legitimacy for their actions (Francis et al., 2009).

A firm's survival is conditioned by formal and informal norms and rules that directly affect its strategic choices (Peng et al., 2008). Organisations are sensitive to environmental influences, cultural influences, and the groups' interests interacting with them (Peng et al., 2009). The focus on the institutional perspective permeates the technical needs of organisational activities that incorporate concerns about institutional pressures. These institutional pressures are responsible for the emergence of organisational forms, processes, strategies, and patterns of interaction (Furubotn \& 
Richter, 2008; Selznick, 1996). Institutions constraint strategies and the behaviour of firms (Dequech, 2011). However, developed and consolidated institutions play an essential role in a healthy market. It is up to the institutions to minimise the uncertainties inherent in human interaction (Furubotn \& Richter, 2008; North, 1990; Peng et al., 2009). Hence, when institutions work well, there will be fewer uncertainties regarding interactions.

Faced with the costs of trade and the unpredictability of human behaviour, institutions provide structural support so that transactions can occur with the lowest uncertainty (Furubotn \& Richter, 2008; Rodrik, 2000). Thus, the more complex the relations of exchange concerning the quantity and variability of the attributes of goods and services, the greater the importance of reliable institutions (North, 1990; Rodrik, 2000). To guide relations, institutions constitute restrictions aimed at directing the individual's choices from attenuating the costs of interaction typical of the trade process (de Groot et al., 2004; Furubotn \& Richter, 2008).

Formal restrictions, or rules, form the visible part of institutions, including trade laws, policies, and contracts. These rules evolve according to the complexity of the transactions and the need to intensify informal restrictions, referencing the relationship between agents, facilitating the exchange process (North, 1990). According to North (1991), formal and informal institutions evolve insofar as they influence each other to some extent. For instance, formal institutions can represent a constrain for the informal environment, as well as the informal institutions exert influence in the formal rules designed. They complement and influence each other, causing what the author calls institutional changes.

Informal institutions also seen are a source of managers' risk perception given the effect they exert in international business (Makhija \& Stewart, 2002; Cao et al., 2018). Informal restrictions that are designed and socially transmitted by culture guide and constrain the conduct of individuals in all spheres of human interaction (Hall \& Soskice, 2001, 2004; Tywoniak et al., 2007).

In trade, these restrictions act to reduce the costs of measurement and execution through non-positive rules only agreed upon between the parties (Dequech, 2011). They consist of codes of ethics, diffuse habits, and values that are difficult to modify
(North, 1990; Peng et al., 2009; Tywoniak et al., 2007).

Therefore, by conditioning the rules that determine individuals' behaviour, institutions confer legitimacy to the acts and practices of managers and companies that end up acting strategically in pursuit of their interests within formal and informal boundaries of a specific institutional framework (Peng et al., 2009; Tywoniak et al., 2007). In this sense, North (1991) assumes that the institutional framework should promote some stability to not interfere with the formal rules and the conduct rules that will determine individuals' and companies' choices.

Otherwise, when formal constraints are not transparent or effective, informal constraints play a more significant role in diluting natural uncertainties in firms' decision-making, prioritising reactions based on network or influence (Hall \& Soskice, 2001). Individuals and companies' bargaining power puts pressure on such stability, causing changes in the institutional framework (North, 1990; Peng et al., 2009).

Thus, institutional characteristics represent the formal and informal rules that coexist in society's economic game, reflecting and describing the external organisational environments (van Hoorn \& Maseland, 2016). Kostova (1997) proposed that institutional characteristics shape the institutional profile of countries, understood as the primary set of institutions that have consolidated over time and that parameterise the functioning of organisations in that country. Adopting institutional literature, Kostova (1997) differentiates institutions in three dimensions: regulatory, cognitive, and normative. The regulatory dimension of the institutional profile covers laws, regulations, and government policies that provide support or restrict organisational behaviour related to the institutions' formal restrictions. The cognitive dimension reflects the mental structures and knowledge shaping and defining how people interpret the available information. The normative dimension, which contemplates social norms and values shared by society, corresponds to informal restrictions.

\section{Uncertainty}

The early concepts of uncertainty have been historically tied to a mathematical and measurement definition.Thiss study used the Knightian definition of 
uncertainty to propose a differentiation between risk and uncertainty and their relations with institutions. According to the seminal work of Knight (1921), uncertainty is seen as a phenomenon in which the results are unknown, and their probabilities of variation are unpredictable. The author additionally classified the uncertainty into two different types:

a) Measurable: This one is based on past events that create what the author called "a priori probability", with a homogeneous distribution in groups of past outcomes.

b) Unmeasurable: This occurs when the probability of possible outcomes is "estimate" by the judgment of the individuals.

Uncertainty has unknown outcomes, while risk represents the uncertainty that the results are known (Mousavi \& Gigerenzer, 2014). Several studies in the field developed the concept of environmental uncertainty like the one that is characterised as "uncertainty about the outcomes of the external environment" (Azar \& Drogendijk, 2014; Magnani \& Zucchella, 2018; Martin et al., 2015), first proposed by Knight (1921). Many others try to measure this environmental uncertainty in different levels and frameworks (Packard et al., 2017; Samsami et al., 2015).

Knight's definition also supports the institutional theory perspective definition of uncertainty. From this perspective, uncertainty is a condition in which an event's probability cannot be established and assured against such occurrence (North, 1991) and is always present in the environment (Francis et al., 2009). Complementary so, NIE proposes that the lack of results in an environment can be mitigated by the institutions' quality, once enhance actor's strategic capacity when faced with challenges (Hall \& Soskice, 2004). This alternative to deal with environmental uncertainties is also linked to making unknown results predictable or turning them into risk.

Transforming uncertainty into risk involves measuring variables present in environmental contexts and making rational decisions based on data and statistics. However, while risk provides safer decision-making environments, it does not encourage agents to deal with entirely unknown and complex factors, promoting a more simplistic assessment of the context (Teece \& Leih, 2016). The concept of risk is most straightforward when compared with uncertainty.

\section{Risk}

According to one of the first distinctions of the concepts of risk and uncertainty, the risk is what happens when decision-makers are unaware of the decisions' results. However, it is possible to calculate the probability of known outcomes (Magnani \& Zucchella, 2018). While uncertainty represents a construct of the incurrence of unexpected events in which their probability cannot be measured, and there is no way to prevent them, risk has a much more specific scope (North, 1991). Knight (1921) defines that risk is associated with one particular adverse event in which its probability of occurrence can be measured. In this case, prevention is considered adequate. Along these lines, risk represents a "known" part of the uncertainty.

If the uncertainty present in an environment lacks results information, we add some knowledge to the unknown part when we have risk, which allows the creation of statistical previsions (Magnani \& Zucchella, 2018; Vahlne \& Johanson, 2017) and possible known outcomes. As opposed to uncertainty, the organisations' managers translate the risk, thus becoming a management tool through the company actions (Müllner, 2016). To reduce transaction costs, uncertainties should be transformed into risks so that a prediction from the variability of results can be possible (North, 1991). Nonetheless, how could this be done? What are the mechanisms that support the firm's decisions, capable of transforming uncertainties into risk? The answer depends on first understanding the definition and the difference between both concepts.

In the new institutional economics, risk occurs by analysing the interaction of the context with the organisation's actions defined by the institution's dynamics (North, 1990). This way, risk management is integrated with the organisation's strategic planning and decisions. Also, although present in this theory, the role of risk is not clearly defined in its determinants, and there is no further differentiation between the concepts of risk and uncertainty (Müllner, 2016). So, we proposed a conceptual development to do that. 


\section{Conceptual Development}

5.1. How risks influence uncertainties and how uncertainties influence risks

In this study, we proposed to analyse the concepts of uncertainty and risk throughout the Knightian definitions and the institutional lens. Based on extant literature, uncertainty and risk are different concepts interacting with each other. Once they could be subsequent concepts, the degree of one is related to the other's degree (Magnani \& Zucchella, 2018).

On the one hand, uncertainty is an inherent condition in the organisational context, referring to "the lack of knowledge regarding the firm's actions" (Magnani \& Zucchella, 2018 p.103). It will always exist. Teece, Peteraf, and Leih (2016) called uncertainty "ubiquitous", an intrinsic characteristic of relations between companies and the market. The unpredictability existent in the market is natural for all firms in different sectors of industries.

On the other hand, the risk may or may not exist. When an environment presents less uncertainty, the measurement of possible actions becomes less problematic, being possible to calculate the impact of the consequence of these actions and the risk inherent to them. In this context of less uncertainty, the risk is present and measurable. Conversely, there may be environments where the prediction of results does not exist; the behaviour of people and markets is unpredictable. For example, in emerging markets, the lack of historical information (Zanini et al., 2009) can lead to an environment that is more subject to uncertainty and less subject to risk measurement.

Said that, how can North (1991) assumptions of institutions transforming uncertainty into risk occur? Several studies tried to explain the interconnection, at the same time the idiosyncratic, between uncertainty and risk (Knight, 1921; Miller, 2007; Hmieleski et al., 2015). Bewley (2002) argue that uncertainty can be turned into risk through the decision making process. Through alternatives discussion and analysis process, managers can turn the non-known outcomes into known ones (Miller, 2007). The logic behind the argument is transforming the subjectivity of uncertainty into "known parts" called risks. For this to happen, the uncertainty is a construct that exists regardless of the risk, thus:
Proposition 1: Uncertainty precedes the risk.

Risks will also influence uncertainty. Risks define systematic and rational thinking for decisionmaking, forcing the decision-maker to find ways to quantify or eliminate the chances of something going wrong, even if they do not do it statistically. Risks are calculable, or at least estimable. The accuracy of risk estimation is based on the ability and possibility to accurately understand the state and predict changes in the environment (Carruthers, 2013).

Thus, unstable scenarios are a source of uncertainty, as opposed to the risk, due to the complexity of the change and the inability to measure possible outcomes. Changeable actors and institutions provide less source of risk to entrepreneurs at the same time that increases uncertainty levels (Young et al., 2018). With this in mind, the likelihood to operate a business in riskier environments are higher once the predictability allows better decision-making. In this regard, the literature reaffirms that the commitment of the firm with its business in riskier environments depends on its tolerance for risk (Johanson \& Vahlne, 1977, 2009; Figueira-de-Lemos \& Hadjikhani, 2014). The balance between the existing risks and the amount of the risk that the company is willing to accept determine strategic choices of engaging or not with business in a location (Clarke, \& Liesch, 2017).

However, as the amount of risk analyses increases, the possibility of inaccuracy in these analyses also increases. The complexity of each risk assessment is cumulative when dealing with multiple assessments, decreasing the probability of understanding and predicting the possible scenarios and outcomes (Johansen, \& Rausand, 2014; Jensen, \& Aven, 2018). Uncertainty arises when the ability to understand and accurately predict outcomes is complex. By the diverse and complex combination of a high number of known factors (risks), the results may be unknown (uncertainty). Hence, we propose that:

Proposition 2: Environments with higher amounts of risk will present higher uncertainty.

\subsection{How institutions influence risk and uncertainty}

It is necessary to understand that an organisation's environment is not static; on the 
contrary, it is subject to constant changes to understand the institutional factors that can influence the levels of risk and uncertainty (Mintzberg et al., 2009). An unstable context is marked by the unpredictability of the individual's future behaviour and a dynamic and complex environment (Siggelkow \& Rivkin, 2005). The environmental changes radiate their effects throughout the institutional and organisational environment, giving rise to a new business environment characterised by environmental risk and uncertainty (Furubotn \& Richter, 2008).

The prominent role of institutions is to reduce uncertainty, primarily through their cognitive function (North, 1991). In this perspective, economic decision-making is strongly influenced by individuals' beliefs and society's cultural heritage (Knight \& North, 1997). The institutions themselves represent a reflection of these cultural heritages built over time and greatly influenced by subjective preferences regarding notions and ideologies rooted in a society or economy.

The social and cultural context, called by North (1990) as informal constraints, act on the cognitive process and rational decision making through the substantive content of institutional rules and cultural symbols and in the ways that social institutions and practices structure and organise the cognitive process itself (Dequech, 2006; Knight \& North, 1997; North, 1990). Thus, institutional, cultural factors are those that exert the most significant influence on uncertainty in relation to exchange, since they are derived from collective legacies and codes of conduct that are broader and deeper, and, therefore, more difficult to change, providing suggestions of possible behaviours to people and firms.

However, as long and gradual changes occur, informal institutions allow for the assimilation of this new behaviour and adaptation to maximise risk and predict standard behaviour. In new international ventures, firms base their strategies on mimetics and reproduce the same assertive behaviour that exists in that environment, even in the subsidiary's internal culture (Francis et al., 2009), since the behaviour is predictable. In this sense, in unstable and random environments, informal restrictions could favour the incidence of risks to a greater degree than uncertainties, as they would print a certain degree of behavioural predictability, allowing the measurement of the consequence of possible actions. In addition, informal restrictions would respond to the environment in which values and patterns of behaviour would change according to opportunities to maximise profitability (Hall \& Taylor, 2003), in less progress, increasing the amount of risk and the predictable results of actions from the company. That is why:

\section{Proposition 3: The strength of informal restrictions is positively related to the risk in an environment.}

Institutional factors related to technological changes, markets and legal and political issues should positively influence environmental uncertainty. This is because the constant technological advances generate a rapid change scenario, forcing the actors to develop an innovative capacity compatible with society's demands (Siggelkow \& Rivkin, 2005).

Regarding formal institutions, political-legal factors do not keep up with the speed of environmental changes, act in disagreement with the new and diverse market configurations, and the exchange relationships in this complex environment end up being driven by undefined rules or rules under definition (Zanini et al., 2009).

As discussed previously, institutions have as their primary function the reduction of uncertainty inherent in human interaction; however, this does not mean that they have a static, unchanging configuration. The formal institutions respond to their environment, evolving and changing, and in this movement, they alter the available choices (North, 1990).

In this sense, it is possible to affirm that economic, political, and legal institutions act to minimise the probability of the occurrence of some event that will frustrate the economic exchanges between organisations. Economic institutions, for example, play a more prominent role in emerging economies by providing market support given the instability of the environment (Peng et al., 2009). In addition, economic institutions affect investment decisions by providing indicators that enable decision making at lower transaction costs, overcoming information asymmetry, and favouring legal stability (Amal \& Seabra, 2007).

Political and legal institutions, in turn, act to minimise the uncertainty from the promotion of stability of the institutional environment. Institutions 
provide the formal rules of the game and modulate the choices of organisations (Hall \& Taylor, 2003). Issues such as the democratic environment, political stability, and the legal framework represent some packaging (North, 1990) that delimit the organisation's opportunities.

Environments can be more restrictive or more flexible based on their institutions. Restrictive environments will become more assertive - more rigid and acting - normative and regulative institutions (Yiu \& Makino, 2002). The level of institutional, legal restriction in an environment determines the degree to which these institutions are enforced and respected and might affect the economic outcomes (Porta et al., 2008).

Institutions, as formal restrictions, are organisational factors that measure and predict results. For instance, the legal system's development, banking sector structure, and industry regulation of contracts (Francis et al., 2009) set rules and predict outcomes in business interactions. These behavioural restrictions will limit the number of possible events and actions that could influence the uncertainty of a determined event. By limiting the number of possible events, the institutional environment will decrease the complexity of risk assessment, making it easier to predict the outcomes in a specific object of analysis. Hence, the more restrictive the institutional environment is, the less possible events and actions are allowed, reducing the amount of uncertainty:

Proposition 4: The strength of formal restrictions in an environment is negatively related to the amount of uncertainty.

To represent these four propositions, Figure 1 illustrates the relationships between risk, uncertainties, and institutions. These effects happen in two ways when we speak about uncertainty and risk. Therefore, the strength and formal and informal institutions can be exerting influence on the levels of uncertainty and risk of the environment. This framework illustrates the direction of the effects which are proposed in our conceptual development. The literature about all these actors made it possible the formulation of this paper and the proposition of these interactions.

To represent these four propositions, Figure 1 illustrates the relationships between risk, uncertainties, and institutions. These effects happen in two ways when we talk about uncertainty and risk. Therefore, the strength and formal and informal change of institutions may be influencing the levels of uncertainty and risk in the environment. The proposed model has two antagonistic relationships and coexists between risk and uncertainty that alternate according to institutional influence.

Figure 1: Risk, uncertainty and institutions

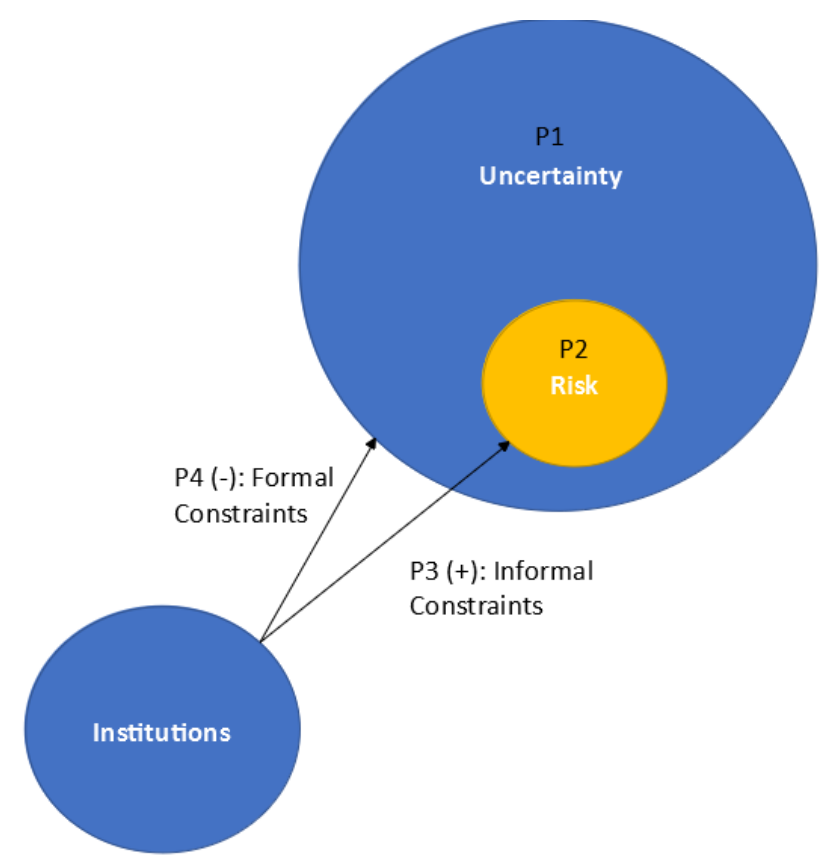

Internext | São Paulo, v.16, n. 3, p. 238-251, sep./dec. 2021 
Thus, there is a positive influence of informal restrictions on risks, an increase in the predictability of events in decision making, and on the other hand, a negative influence of formal restrictions on uncertainty, promoting, even temporarily, environmental instability. This chart illustrates the direction of the effects that are proposed by four propositions in the conceptual development.

\subsection{Research Agenda}

The theoretical discussion of this work aims to deepen the analysis of literature and pre-existing concepts. The Knightian perspective and the concepts of uncertainty and risk are clarified and applied to the institution's lens. This early definition was necessary to support propositions 3 and 4 . While informal institutions set a firm's behaviour pattern in a determined location, they produce a source for risk. As the known part of uncertainty, risk allows the firm to behave and practice mimetic strategy for international entry purposes. For example, for future researches, it is possible to develop a further analysis of these relationships. Suitable future research questions are: What are the informal restrictions that boost mimetic strategies? When can cultural aspects, such as socially transmitted beliefs and values - inside and outside companies - pose risks to international strategy? Are the firm's behaviour patterns a source of country risk? The analysis of these relationships could benefit significantly from micro-foundations studies to establish better constructs and their antecedents.

Additionally, researchers can use the in-depth explanations provided here through empirical tests for proposition 4. In proposition 4, we reinforce the role of formal restrictions in an environment affecting the levels of uncertainty negatively. This proposition is not new and is supported by previews literature (Francis et al., 2009). However, these relationships depicted in this study offer a better conceptual background to support them. With a broader understanding of economic concepts of uncertainty and risk, the future research questions could be settled by the real meaning. In this sense, futures studies can develop the following questions: What are the legal restrictions that affect country levels of uncertainty in international business? Is the sectorial legislation acting reducing uncertainties in global or local business agreements? If so, these legal restrictions might also be a source of risk?

\section{Conclusion}

In this study, we explain the relationships between institutions, uncertainty and risk. We intend to give a better explanation of the previously established relationships. First, we seek to summarise the concepts of risk and uncertainty, given their multiple interpretations. For this, we use the economic perspective and defend that although close and related, risk and uncertainty are distinct concepts endowed with particular characteristics, such as the presence of predictability (Knight, 1921). They are also concepts that can be antecedent (proposition 1) and consequent (proposition 2) insofar as they interact with the strategies and institutions of a given environment.

The companies' strategies can change according to the risks and uncertainties of the environment. Ass proposed in the study model, it is essential that these two constructs, subsequent and coexisting, can alternate responding to the stimuli exerted by formal and informal restrictions. In proposition 3 , it is expected to explore how informal institutions act on the risks inherent in a given decision context. According to the literature, economic actions reflect the mental models shared collectively (Knight \& North, 1997; Tamanaha, 2015) and these shared models, reflected in values, beliefs, culture and language, promote economic interaction in a greater degree of predictability, converting the uncertainty naturally present in the business environment, in plausible risks.

In proposition 4, we intend to relate the formal restrictions to the incidence of uncertainties. According to theoretical development, norms, governments and laws that represent formal restrictions of institutions are not effective in monitoring environmental changes (Zanini et al., 2009). Thus, formal institutions end up evolving and transmitting changes more slowly. As a result, the predictability of events, especially in the face of complex and constantly changing contexts, is compromised, generating a greater degree of uncertainty. Even so, when formal institutions are able to contemplate environmental characteristics, they become more adherent to society and, consequently, more respected (Porta et al., 2008). The effect of this dynamic is reflected in the capacity of formal institutions to limit the occurrence of unpredictable events and, thus, negatively influence 
the degree of uncertainty present in the environment.

The present study induces the following contributions. On a practical level, we can point out that institutions are more efficient when long-term investments are foreseen, such as deciding to enter the business in a specific country or region. Unlike formal institutions, informal restrictions, since they are less volatile, can be more effective as an instrument for converting uncertainties in the environment into risks, as they reflect changes in values and behaviour patterns according to the opportunities to maximise profitability.

As for academic considerations, one of the contributions consists of the approach to risk and uncertainty, aiming to provide further clarity to the concept of uncertainty and its relationship with risk. In addition, this paper seeks to contribute to the ENI literature, expanding the understanding of institutions and their relationship with risks and uncertainties. Classical authors like North (1991) recognise and debate the role of institutions in controlling and forecasting risks in strategic organisational decisions; however, the dynamics of this relationship are restricted to transaction and information processing costs. The paper seeks to broaden the discussion by exploring these relationships, differentiating the role of formal and informal institutions, and taking a look to predict how this action could occur.

\section{References}

Agboola, A. O. (2015). Neoclassical economics and new institutional economics: An assessment of their methodological implication for property market analysis. Property Management, 33(5), 412-429. https://doi.org/10.1108/PM-12-2014-0055

Amal, M., \& Seabra, F. (2007). Determinantes do investimento direto externo (IDE) na América Latina: uma perspectiva institucional. Revista Economia, $8(2), 231-247$.

Azar, G., \& Drogendijk, R. (2014). Psychic Distance, Innovation, and Firm Performance. Management International Review, 54(5), 581-613.

Bewley, T. F. (2002). Knightian decision theory. Part I. Decisions in Economics and Finance, 25, 79110. https://doi.org/10.1007/s102030200006
Cao, Z., Li, Y., Jayaram, J., Liu, Y., \& Lumineau, F. (2018). A meta-analysis of the exchange hazardsinterfirm governance relationship: An informal institutions perspective. Journal of International Business Studies, 49(3), 303-323.

Carruthers, B. G. (2013). From uncertainty toward risk: the case of credit ratings. Socio-Economic Review, 11(3), 525-551. https://doi.org/10.1093/ser/mws027

Clarke, J. E., \& Liesch, P. W. (2017). Wait-and-see strategy: Risk management in the internationalization process model. Journal of International Business Studies, 48(8), 923-940.

Contractor, F. J., Dangol, R., Nuruzzaman, N., \& Raghunath, S. (2020). How do country regulations and business environment impact foreign direct investment (FDI) inflows? International Business Review, 29(2), 101640. https://doi.org/10.1016/j.ibusrev.2019.101640

Cuervo-Cazurra, A., Ciravegna, L., Melgarejo, M., \& Lopez, L. (2018). Home country uncertainty and the internationalization-performance relationship: Building an uncertainty management capability. Journal of World Business, 53(2), 209-221. https://doi.org/10.1016/i.jwb.2017.11.002

de Groot, H. L. F., Linders, G., Rietveld, P., \& Subramanian, U. (2004). The Institutional Determinants of Bilateral Trade Patterns. Kyklos, 57(1), 103-123. https://doi.org/10.1111//.00235962.2004.00245.x

Dequech, D. (2006). The new institutional economics and the theory of behaviour under uncertainty. Journal of Economic Behavior and Organization, 59(1), 109-131. https://doi.org/10.1016/i.jebo.2004.03.012

Dequech, D. (2011). Uncertainty: A Typology and Refinements of Existing Concepts. Journal of Economic Issues, 45(3), 621-640. https://doi.org/10.2753/JEl0021-3624450306

Dequech, D. (2018). Institutions in the economy and some institutions of mainstream economics: From the late 1970s to the 2008 financial and economic crisis. Journal of Post Keynesian Economics, 41(3), 478-506. https://doi.org/10.1080/01603477.2018.1431796 
Duncan, R. B. (1972). Characteristics of Organizational Environments and Perceived Environmental Uncertainty. Administrative Science Quarterly, 17(3), https://doi.org/10.2307/2392145

Francis, J., Zheng, C., \& Mukherji, A. (2009). An Institutional Perspective on Foreign Direct Investment. Management International Review, 49(5), 565-583. https://doi.org/10.1007/s11575$\underline{009-0011-x}$

Figueira-de-Lemos, F., \& Hadjikhani, A. (2014). Internationalization processes in stable and unstable market conditions: Towards a model of commitment decisions in dynamic environments. Journal of World Business, 49(3), 332-349.

Furubotn, E. G., \& Richter, R. (2008). The New Institutional Economics - A Different Approach to Economic Analysis. Economic Affairs, 28(3), 15-23. https://doi.org/10.1111/j.1468-0270.2008.00839.x

Garner, W. R. (1962). Uncertainty and structure as psychological concepts. In uncertainty and structure as psychological concepts. Wiley.

Hall, P. A., \& Soskice, D. (2001). An introduction to varieties of capitalism. In op. cit.

Hall, P. A., \& Soskice, D. (2004). Varieties of Capitalism and Institutional Complementarities BT Institutional Conflicts and Complementarities: Monetary Policy and Wage Bargaining Institutions in EMU (R. Franzese, P. Mooslechner, \& M. Schürz (eds.); pp. 43-76). Springer US. https://doi.org/10.1007/978-1-4757-4062-2 3

Hall, P. A., \& Taylor, R. C. R. (2003). As três versões do neo-institucionalismo. Lua Nova: Revista de Cultura e Política, 58, 193-223. https://doi.org/10.1590/S010264452003000100010

Hmieleski, K. M., Carr, J. C., \& Baron, R. A. (2015). Integrating discovery and creation perspectives of entrepreneurial action: The relative roles of founding CEO human capital, Social capital, and psychological capital in contexts of risk versus uncertainty. Strategic Entrepreneurship Journal, 9, 289-312. https://doi.org/10.1002/sej.1208
Jensen, A., \& Aven, T. (2018). A new definition of complexity in a risk analysis setting. Reliability Engineering \& System Safety, 171, 169-173.

Johansen, I. L., \& Rausand, M. (2014). Defining complexity for risk assessment of sociotechnical systems: A conceptual framework. Proceedings of the Institution of Mechanical Engineers, Part O: Journal of Risk and Reliability, 228(3), 272-290.

Johanson, J., \& Vahlne, J. E. (1977). The internationalization process of the firm: A model of knowledge development and increasing foreign market commitments. Journal of International Business Studies, 8(1): 23-32.

Johanson, J., \& Vahlne, J. E. (2009). The Uppsala internationalization process model revisited: From liability of foreignness to liability of outsidership. Journal of international business studies, 40(9), 14111431.

Keeney, R. L. (1982). Decision Analysis: an Overview. Oper Res, V 30(N 5), 803-838. https://doi.org/10.2307/2285355

Kerremans, B. (1996). Do Institutions Make a Difference? Non-Institutionalism, NeoInstitutionalism, and the Logic of Common DecisionMaking in the European Union. Governance, 9(2), 217-240.

https://doi.org/10.1111/j.14680491.1996.tb00239.x

Knight, F. H. (1921). Risk, Uncertainty and Profit. Houghton Mifflin.

Knight, J., \& North, D. (1997). Explaining Economic Change: The Interplay Between Cognition and Institutions. Legal Theory, 3(3), 211-226. https://doi.org/10.1017/S1352325200000768

Kostova, T., \& Roth, K. (2002). Adoption of an Organizational Practice by Subsidiaries of Multinational Corporations: Institutional and Relational Effects. Academy of Management Journal, 45(1), 215-233. https://doi.org/10.5465/3069293

Lewis, Y., \& Bozos, K. (2019). Mitigating postacquisition risk: the interplay of cross-border uncertainties. Journal of World Business, 54(5), 100996. https://doi.org/10.1016/i.jwb.2019.100996 
Liesch, P. W., Welch, L. S., \& Buckley, P. J. (2011). Risk and Uncertainty in Internationalization and International Entrepreneurship Studies: Review and Conceptual Development. Management International Review, 51(6), 851-873. https://doi.org/10.1007/s11575-011-0107-y

Magnani, G., \& Zucchella, A. (2018). Uncertainty in Entrepreneurship and Management Studies: A Systematic Literature Review. International Journal of Business and Management, 13(3), 98. https://doi.org/10.5539/ijbm.v13n3p98

Makhija, M. V., \& Stewart, A. C. (2002). The effect of national context on perceptions of risk: A comparison of planned versus free-market managers. Journal of International Business Studies, 33(4), 737 756.

Martin, G., Gözübüyük, R., \& Becerra, M. (2015). Interlocks and firm performance: The role of uncertainty in the directorate interlock-performance relationship. Strategic Management Journal, 36(2), 235-253. https://doi.org/10.1002/smj.2216

Miller K.D. 2007. Risk and rationality in entrepreneurial processes. Strategic Entrepreneurship Journal 1(1/2): 57- 74.

Mintzberg, H., Lampel, J., \& Ahlstrand, B. W. (2009). Strategie safari: uw complete gids door de jungle van strategisch management (2nd ed.). Pearson Education.

Mousavi, S., \& Gigerenzer, G. (2014). Risk, uncertainty, and heuristics. Journal of Business Research, 67(8), 1671-1678. https://doi.org/10.1016/j.jbusres.2014.02.013

Müllner, J. (2016). From uncertainty to risk-A risk management framework for market entry. Journal of World Business, 51(5), 800-814. https://doi.org/10.1016/j.jwb.2016.07.011

North, D. C. (1990). Institutions, Institutional Change and Economic Performance. Cambridge University Press. https://books.google.com.br/books?id=oFnWbTagN PYC
North, D. C. (1991). Institutions. Journal of Economic Perspectives, 5(1), 97-112. https://doi.org/10.1257/jep.5.1.97

Packard, M. D., Clark, B. B., \& Klein, P. G. (2017). Uncertainty Types and Transitions in the Entrepreneurial Process. Organization Science, 28(5), 840-856. https://doi.org/10.1287/orsc.2017.1143

Peng, M. W., Sun, S. L., Pinkham, B., \& Chen, H. (2009). The Institution-Based View as a Third Leg for a Strategy Tripod. Academy of Management Perspectives, 23(3), 63-81.

Peng, M. W., Wang, D. Y. L., \& Jiang, Y. (2008). An institution-based view of international business strategy: a focus on emerging economies. Journal of International Business Studies, 39(5), 920-936. https://doi.org/10.1057/palgrave.jibs.8400377

Porta, R. La, Lopez-de-Silanes, F., \& Shleifer, A. (2008). The Economic Consequences of Legal Origins. Journal of Economic Literature, 46(2), 285-332. https://doi.org/10.1257/jel.46.2.285

Samsami, F., Khodadad Hosseini, S. H., Kordnaeij, A., \& Azar, A. (2015). Managing Environmental Uncertainty: From Conceptual Review to Strategic Management Point of View. International Journal of Business and Management, 10(7). https://doi.org/10.5539/ijbm.v10n7p215

Selznick, P. (1996). Institutionalism "Old" and "New." Administrative Science Quarterly, 41(2), 270. https://doi.org/10.2307/2393719

Siggelkow, N., \& Rivkin, J. W. (2005). Speed and Search: Designing Organisations for Turbulence and Complexity. Organization Science, 16(2), 101-122. https://doi.org/10.1287/orsc.1050.0116

Suchman, M. C. (1995). Managing legitimacy: Strategic and institutional approaches. Academy of management review, 20(3), 571-610.

Tamanaha, B. Z. (2015). The knowledge and policy limits of New Institutional Economics on development. Journal of Economic Issues, 49(1), 89109. 
Teberga, P. M. F., Oliva, F. L., \& Kotabe, M. (2018). Risk analysis in introduction of new technologies by start-ups in the Brazilian market. Management Decision, 56(1), 64-86. https://doi.org/10.1108/MD$\underline{\text { 04-2017-0337 }}$

Teece, D., \& Leih, S. (2016). Uncertainty, Innovation, and Dynamic Capabilities: An Introduction. California Management Review, 58(4), 5-12. https://doi.org/10.1525/cmr.2016.58.4.5

Tywoniak, S., Galvin, P., \& Davies, J. (2007). New Institutional Economics' contribution to strategic groups analysis. Managerial and Decision Economics, 28(3), 213-228. https://doi.org/10.1002/mde.1323

Vahlne, J.-E., \& Johanson, J. (2017). From internationalization to evolution: The Uppsala model at 40 years. Journal of International Business Studies, 48(9), 1087-1102. https://doi.org/10.1057/s41267017-0107-7
Williamson, O. E. (1976). The Economics of Internal Organization: Exit and Voice in Relation to Markets and Hierarchies. The American Economic Review, 66(2), 369-377. http://www.jstor.org/stable/1817249

Yiu, D., \& Makino, S. (2002). The Choice Between Joint Venture and Wholly Owned Subsidiary: An Institutional Perspective. Organization Science, 13(6), 667-683. https://doi.org/10.1287/orsc.13.6.667.494

Young, S. L., Welter, C., \& Conger, M. (2018). Stability vs. flexibility: The effect of regulatory institutions on opportunity type. Journal of International Business Studies, 49(4), 407-441.

Zanini, M. T. F., Lusk, E. J., \& Wolff, B. (2009). Confiança dentro das organizações da nova economia: uma ma análise empírica $s$ sobre as conseqüências bre da incerteza institucional. RAC Revista de Administração Contemporânea, 13(1), 7291.

https://www.redalyc.org/articulo.oa?id=84013105

\section{ABOUT THE AUTHORS}

Stephanie Tonn Goulart Moura - Fundação Universidade Regional de Blumenau - FURB, Santa Catarina, (Brasil). E-mail: stephaniemr600@gmail.com Orcid id: https://orcid.org/0000-0001-8668-8325

Christian Daniel Falaster - Fundação Universidade Regional de Blumenau - FURB, Santa Catarina, (Brasil). E-mail: christianfalaster@gmail.com Orcid id: https://orcid.org/0000-0001-9502-4475

Christine Elena Bianchi - Fundação Universidade Regional de Blumenau - FURB, Santa Catarina, (Brasil). E-mail: christinebianchi@gmail.com Orcid id: https://orcid.org/0000-0002-6415-9657

Érica de Souza Mazato - Fundação Universidade Regional de Blumenau - FURB, Santa Catarina, (Brasil). E-mail: erica.mazato@gmail.com Orcid id: https://orcid.org/0000-0001-7806-3704

Laura Taysa Espig - Fundação Universidade Regional de Blumenau - FURB, Santa Catarina, (Brasil). E-mail: laura taysa@hotmail.com Orcid id: https://orcid.org/0000-0003-0486-7042 


\title{
COMO AS INSTITUIÇÕES MOLDAM A INCERTEZA E O RISCO
}

\author{
Stephanie Tonn Goulart Moura, Christian Daniel Falaster, Christine Elena Bianchi, \\ Érica de Souza Mazato \& Laura Taysa Espig \\ Fundação Universidade Regional de Blumenau - FURB, Santa Catarina, (Brasil)
}

\begin{tabular}{l}
\hline DETALHES DO ARTIGO \\
\hline Histórico do Artigo: \\
Recebido: 11 de Abril de 2020 \\
Aceito: 29 de Junho de 2021 \\
Disponível online: 01 de Setembro de \\
2021 \\
Sistema de revisão “Double blind review” \\
Editor Científico \\
Ilan Avrichir \\
\hline Palavras-chaves: \\
Nova Economia Institucional \\
Risco \\
Incerteza \\
Instituições \\
Tomado de decisão
\end{tabular}

RESUMO
Objetivo: O estudo propõe uma estrutura conceitual sobre como as instituições
influenciam o risco e a incerteza. Além das nuances na definição dos conceitos
na literatura existente, o papel das instituições na definição de riscos e
incertezas permanece pouco estudado. Este artigo adota a perspectiva da nova
economia institucional (NIE) para revisitar os conceitos de risco e incerteza e
fornecer uma reflexão mais profunda sobre suas interações com instituições
formais e informais.
Método: Nosso modelo conceitual é baseado em quatro proposições que
sustentam uma explicação teórica sobre as relações entre instituições e
incertezas, instituições e riscos, e incertezas e riscos.
Principais Resultados: Embora as instituições formais tenham um papel
principal na redução das incertezas, as instituições informais podem ser vistas
como uma fonte de risco. Essas descobertas implicam nas decisões estratégicas
das empresas. Nesse sentido, também fornecemos uma agenda de pesquisa
para futuros estudos empíricos na área.
Originalidade/valor: O estudo destaca a importância das instituições para as
empresas lidarem com riscos e incertezas. As instituições têm um papel
primordial na definição da "parte conhecida" da incerteza, permitindo às
empresas avaliar os diferentes cenários para a tomada de decisão.
Contribuições teórico/metodológicas: Este estudo diferencia a interação de
risco e incerteza de acordo com a teoria institucional. Além disso, oferecemos
uma discussão acadêmica de como as instituições formais e informais podem
moldar riscos e incertezas.




\title{
CÓMO LAS INSTITUCIONES DAN FORMA A LA INCERTIDUMBRE Y EL RIESGO
}

\author{
Stephanie Tonn Goulart Moura, Christian Daniel Falaster, Christine Elena Bianchi, \\ Érica de Souza Mazato \& Laura Taysa Espig \\ Fundação Universidade Regional de Blumenau - FURB, Santa Catarina, (Brasil)
}

\begin{tabular}{|c|c|}
\hline DETALLES DEL ARTÍCULO & RESUMEN \\
\hline $\begin{array}{l}\text { Historia del Artículo: } \\
\text { Recibido: } 11 \text { Abril } 2020 \\
\text { Aceptado: } 29 \text { Junio } 2021 \\
\text { Disponible en línea: } 01 \text { de Septiembre } \\
\text { de } 2021 \\
\text { Double Blind Review System } \\
\text { Editor Científico } \\
\text { Ilan Avrichir } \\
\text { Palabras-clave: } \\
\text { Nueva economía institucional } \\
\text { Riesgo } \\
\text { Incertidumbre } \\
\text { Instituciones } \\
\text { Toma de decisiones }\end{array}$ & $\begin{array}{l}\text { Propósito: El estudio propone un marco conceptual sobre cómo las } \\
\text { instituciones influyen en el riesgo y la incertidumbre. Además de los } \\
\text { matices en la definición de conceptos en la literatura existente, el papel de } \\
\text { las instituciones en la definición de riesgos e incertidumbres sigue siendo } \\
\text { poco estudiado. Este artículo adopta la perspectiva de la nueva economía } \\
\text { institucional (NIE) para revisar los conceptos de riesgo e incertidumbre y } \\
\text { brindar una reflexión más profunda sobre sus interacciones con las } \\
\text { instituciones formales e informales. } \\
\text { Método: Nuestro modelo conceptual se basa en cuatro proposiciones que } \\
\text { sustentan una explicación teórica sobre las relaciones entre instituciones } \\
\text { e incertidumbres, instituciones y riesgos e incertidumbres y riesgos. } \\
\text { Resultados principales: Aunque las instituciones formales juegan un papel } \\
\text { importante en la reducción de la incertidumbre, las instituciones } \\
\text { informales pueden verse como una fuente de riesgo. Estos hallazgos } \\
\text { implican las decisiones estratégicas de las empresas. En este sentido, } \\
\text { también brindamos una agenda de investigación para futuros estudios } \\
\text { empíricos en el área. } \\
\text { Originalidad/valor: El estudio destaca la importancia de las instituciones } \\
\text { para que las empresas se enfrenten a riesgos e incertidumbres. Las } \\
\text { instituciones juegan un papel clave en la definición de la "parte conocida" } \\
\text { de la incertidumbre, permitiendo a las empresas evaluar diferentes } \\
\text { escenarios para la toma de decisiones. } \\
\text { Contribuciones teóricas/metodológicas: Este estudio diferencia la } \\
\text { interacción del riesgo y la incertidumbre según la teoría institucional. } \\
\text { Además, ofrecemos una discusión académica sobre cómo las instituciones } \\
\text { formales e informales pueden moldear los riesgos y las incertidumbres. }\end{array}$ \\
\hline
\end{tabular}

\section{How to cite this article}

Moura, S. T. G., Falaster, C. D., Bianchi, C. E., Mazato, Érica de S., \& Espig, L. T. (2021). How Institutions Shape Uncertainty and Risk. Internext, 16(3), 238-251. https://doi.org/10.18568/internext.v16i3.604 